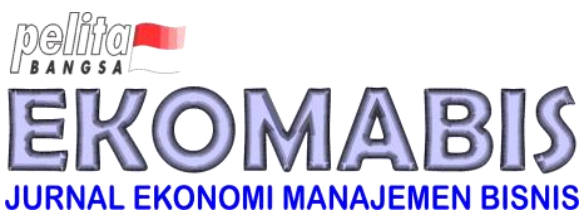

\title{
Kualitas Antarmuka Terhadap Minat Beli: Dimediasi Kepercayaan Konsumen pada Aplikasi Belanja Online
}
(Interface Quality on Purchase Intention: Mediated by Consumer Trust in Online Shopping Applications)

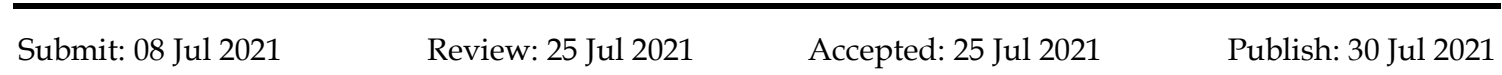

\section{Tukino${ }^{1}$; Preatmi Nurastuti2 ${ }^{2}$ Nani Hartati33; Nining Yuningsih ${ }^{4}$; Muhamad Sudharsono ${ }^{5}$}

\begin{abstract}
Abstrak
Penelitian menguji model pengaruh kualitas antarmuka terhadap minat beli konsumen dengan variabel mediasi kepercayaan konsumen kepada penjual di aplikasi belanja online Shopee.com. Penelitian menggunakan pendekatan kuantitatif dengan sampel konsumen Shopee.com sebanyak 152 orang. Analisis menggunakan model struktural diolah software SMARTPLS 3.0. Hasil penelitian ini membuktikan bahwa kualitas antarmuka tidak berpengaruh terhadap minat beli, kualitas antarmuka berpengaruh terhadap kepercayaan, dan kepercayaan berpengaruh terhadap minat beli. Kepercayaan memediasi kualitas antarmuka terhadap minat beli konsumen pada aplikasi belanja online Shopee.com, sehingga tanpa kepercayaan maka tidak akan ada minat beli pada konsumen belanja online. Kata Kunci: kualitas antarmuka, kepercayaan, minat beli
\end{abstract}

\begin{abstract}
The study aims to examine the model of the influence of interface quality on consumer buying interest with the mediating variable of consumer trust in sellers in the Shopee.com online shopping application. The study uses a quantitative approach with a sample of 152 Shopee.com consumers. Analysis using a structural model processed by SMARTPLS 3.0 software. The results of this study prove that the quality of the interface has no effect on buying interest, the quality of the interface has an effect on trust, and trust has an effect on buying interest. Trust mediates the effect of interface quality on consumer buying interest in the Shopee.com online shopping application, so without trust there will be no buying interest in online shopping consumers.
\end{abstract}

Keywords: interface quality, trust, intention to buy

Kode JEL:

\footnotetext{
1 "Prodi Magister Manajemen Universitas Pelita Bangsa"; mmkino202010050@gmail.com

2 "Prodi Manajemen Universitas Pelita Bangsa"; preatminurastuti@gmail.com

3 "Prodi Manajemen Universitas Pelita Bangsa"; nani.hartati@pelitabangsa.ac.id

4 "Prodi Manajemen Universitas Pelita Bangsa"; nining.rasha2002@gmail.com

5 "Prodi Magister Manajemen Universitas Pelita Bangsa"; ahmad@pelitabelajar.com
} 


\section{Pendahuluan}

Tren belanja yang saat ini berkembang di seluruh dunia adalah belanja online. Pada saat terjadi pandemi Covid-19, masyarakat tidak diperbolahkan melakukan aktivitas di luar rumah sehingga transaksi online semakin tinggi. Semakin banyak masyarakat yang menggunakan telepon pintar mereka untuk melakukan pembelian barang dan jasa menggunakan aplikasi belanja online. Pada tahun 2021, penduduk Indonesia berjumlah 274,9 juta jiwa, dimana terdapat 202,6 juta jiwa yang menjadi pengguna internet (atau $73,7 \%$ dari populasi Indonesia) dan jumlah pengguna media sosial aktif sebanyak 170 juta jiwa (atau 61,8\% dari populasi Indonesia). Dibandingkan dengan tahun 2020, maka terjadi kenaikan jumlah penduduk Indonesia sebanyak 2,9 juta jiwa, dengan penambahan jumlah pengguna internet sebanyak 27 juta jiwa (atau naik 15,5\%), dan penambahan jumlah pengguna media ssosial aktif sebanyak 10 juta jiwa (atau naik 6,3\%) (Nurdian, 2021).

Maraknya belanja online terjadi di seluruh dunia, termasuk di Indoensia. Pada tahun 2021, jumlah populasi berusia 15 tahun keatas yang melakukan pembelian online adalah $11,2 \%$ dari jumlah penduduk Indonesia, yang didominasi oleh konsumen wanita $(12,9 \%)$ sedangkan pria yang berbelanja online hanya $9,4 \%$ dari total populasi Indonesia. Jumlah penduduk yang mengunjungi website ritel atau toko online adalah $87,3 \%$ dari seluruh populasi Indoensia (Nurdian, 2021). Besarnya jumlah orang yang mengakses toko online tentu sangat menarik sebagai pangsa pasar yang sangat besar. Tidak perlu modal besar untuk memulai bisnis online yang mampu menjangkau seluruh Indonesia, bahkan seluruh dunia. Hanya perlu mendownload aplikasi belanja online seperti Shopee, Bukalapak, Tokopedia, Bhinneka, Lazada, Blibli, JD ID, Zalora, Orami. Indonesia adalah negara dnegan pengguna e-commerce tertinggi di dunia. Produk yang menjadi primadona di e-commerce Indonesia adalah produk-produk fesyen (databoks, 2021). Transaksi yang dilakukan sebagian besar menggunakan e-wallet seperti OVO, Shopee Pay, Link aja, Gopay, DANA (databoks, 2021).

Penelitian-penelitian mengenai e-commerce semakin berkembang seiring dengan perkembangan perdagangan online (Wuryandari, Vincentiar, \& Permana, 2019; Alwafi \& Magnadi, 2016; Apriyana, Ariyanti, \& Sumrahadi, 2017; Hanafi, 2020). Semua aplikasi belanja online tentunya menginginkan tingginya transaksi perdagangan dengan memanfaatkan sistem belanja online yang dapat menghemat waktu untuk memilih dan memutuskan membeli suatu produk. Besar kecilnya jumlah transaksi belanja melalui aplikasi belanja online tentu tidak lepas dari daya tarik aplikasi tersebut di mata konsumen. Semakin menarik dan informatif aplikasi belanja online, maka semakin banyak orang yang berminat untuk melakukan belanja online (Halim, 2019). Akan tetapi ada pula penelitian yang menghasilkan temuan bahwa kualitas antarmuka yang dapat dilihat dalam bentuk visual pada telepon pintar tidak berpengaruh terhadap minat konsumen untuk membeli suatu produk secara online (Patel, Das, Chatterjee, \& Shukla, 2020).

Perbedaan temuan penelitian menunjukkan perlunya dilakukan penelitian lebih lanjut. Penelitian ini menguji kembali dan memasukkan variabel kepercayaan konsumen untuk dapat menjelaskan hubungan kausal kualitas antarmuka terhadap minat beli konsumen yang menggunakan aplikasi belanja online. Tampilan dan desain yang informatif akan memberikan keyakinan atau kepercayaan konsumen pada produk yang ditawarkan (Apriyana, Ariyanti, \& Sumrahadi, 2017). Kepercayaan konsumen pada kemampuan 
aplikasi memberikan apa yang dibutuhkan membuat ketertarikan dan minta konsumen meningkat (Hadining, Haryanti, \& Munajat, 2020).

Konfirmasi perbedaan temuan dan menambahkan kepercayaan sebagai pemediasi menjadi fokus penelitian ini. Oleh karena itu, penelitian hendak menguji model pengaruh kualitas antarmuka terhadap minat beli dan melalui kepercayaan konsumen di aplikasi belanja online Shopee.com.

\section{Metodologi}

\subsection{Pengembangan Model}

\subsubsection{Kualitas Antarmuka Terhadap Minat Beli;}

Antar muka (interface) adalah garda terdepan pada alat digital. Antarmuka merupakan bentuk komunikasi antara pengguna dengan sistem operasi yang ada di dalam alat digital (Watulingas \& Permana, 2020). Antarmuka yang ada pada telepon pintar (smartphone) memungkinkan manusia sebagai pengguna dapat berinteraksi dengan perangkat keras dan lunak telepon pintar tersebut melalui fitur-fitur, desain, tata letak, kombinasi warna, besar kecilnya huruf, visual, audio, kejelasan, kelengkapan dan akurasi informasi yang disampaikan, dan lain sebagainya (Lin, Yeh, \& Yu, 2016).

Kualitas antarmuka dapat diukur menggunakan beberapa dimensi. Kualitas antar muka ditunjukkan dengan adanya kelengkapan teknis yang aman, interaktif dan mudah digunakan, ditambah dengan isi web yang berguna, lengkap, jelas, unik, membahas topik terkini, serta didukung dengan kualitas tampilan web yang menarik, terorganisir, pemilihan gambar, huruf dan warna yang tepat (Aladwani \& Palvia, 2002). Dimensi kualitas antarmuka pada aplikasi belanja online meliputi tiga hal yaitu kualitas informasi, kualitas tata letak, dan kualitas visual (Patel, Das, Chatterjee, \& Shukla, 2020). Tujuan konsumen dalam berbelanja online adalah mendapatkan informasi yang berkualitas mengenai produk, harga, dan kebijakan layanan konsumen, sehingga interface yang berkualitas harus memberikan informasi yang jelas, tepat, dan lengkap (Wuryandari, Vincentiar, \& Permana, 2019; Vu, Thang, \& Mai, 2020). Interface yang informatif harus didukung dengan tata letak yang menarik konsumen untuk melakukan pembelian, sebagaimana seorang konsumen yang memasuki sebuah toko akan melihat tampilan fasilitas toko yang menarik (Patel, Das, Chatterjee, \& Shukla, 2020) dan memudahkannya berbelanja (Joewono, Ramadoni, \& Yumte, 2019; Vu, Thang, \& Mai, 2020). Ketika konsumen melihat interface yang memiliki kombinasi gambar, warna dan kalimat yang menyatu menjadi sebuah tampilan visual yang membangkitkan keinginan untuk membeli, maka secara keseluruhan akan tercipta sebuah penawaran yang memiliki daya pikat bagi konsumen untuk membeli barang dan jasa melalui aplikasi belanja online (Patel, Das, Chatterjee, \& Shukla, 2020; Wuryandari, Vincentiar, \& Permana, 2019). Semakin bagus kualitas antarmuka, maka semakin besar daya pikat bagi konsumen untuk membeli produk yang ditawarkan melalui website e-commerce (Halim, 2019).

H1 : Kualitas Antarmuka berpengaruh terhadap Minat Beli

\footnotetext{
“LPP Universitas Pelita Bangsa” $\quad$ Page | 181
} 


\subsubsection{Kualitas Antarmuka Terhadap Kepercayaan}

Transaksi bisnis harus terjalin berlandaskan kepercayaan. Konsumen aplikasi belanja online yang tidak melakukan tatap muka dengan penjual dapat menjadikan unsur kepercayaan menjadi kunci keberlanjutan transaksi dalam jangka panjang (Roy, Dewit, \& Aubert, 2001). Konsumen dan penjual yang terpisah jarak, masing-masing pihak mengharapkan adanya integritas untuk saling memegang janji dan komitmen yang telah disepakati. Kedua belah pihak harus memiliki kesamaan aksi untuk bertindak saling menguntungkan supaya transaksi dapat diselesaikan secara online melalui aplikasi belanja online (Roy, Dewit, \& Aubert, 2001). Konsumen dan penjual tidak melakukan tindakan yang memanfaatkan peluang dan mengambil kesempatan untuk berbuat curang (Kinasih \& Albari, 2012). Kualitas antarmuka yang dilakukan dengan interaktif antara konsumen dengan sistem aplikasi belanja online akan menyebabkan konsumen mendapatkan informasi yang tepat sehingga terbangun rasa percaya konsumen kepada penjual (Apriyana, Ariyanti, \& Sumrahadi, 2017). Kualitas antarmuka memiliki peranan penting dalam membangun kepercayaan konsumen sebagaimana sebuah toko tradisional menempatkan tenaga penjualnya untuk memberikan informasi dan memberikan kemudahan kepada konsuemn untuk memilih produk dan melakukan transaksi (Jin \& youngho Jin, 2006). Semakin meyakinkan kualitas antarmuka pada aplikasi belanja online, maka semakin tinggi tingkat kepercayaan konsumen bahwa penjual tidak melakukan tindakan tercela (Halim, 2019; Apriyana, Ariyanti, \& Sumrahadi, 2017).

H2 : Kualitas Antarmuka berpengaruh terhadap Kepercayaan

\subsubsection{Kepercayaan Terhadap Minat Beli}

Kepercayaan merupakan dasar yang melandasi dilakukannya transaksi online. Kegiatan perdagangan dan bisnis hanya akan terlaksana apabila terdapat rasa saling percaya antara penjual dan konsumennya (Norhermaya \& Soesanto, 2016). Penjual yang amanah adalah penjual yang dapat dipercaya, yang mampu memenuhi janji dan dapat diandalkan. Penjual yang terpercaya dapat dilihat dari rekam jejaknya selama melakukan transaksi bisnis dengan semua konsumennya. Reputasi penjual yang dapat dilihat dari testimoni konsumen sebelumnya dan terekam dalam skala penilaian (bintang) yang diberikan oleh konsumen, juga merupakan petunjuk tinggi rendahnya kemampuan penjual untuk dapat dipercaya (Alwafi \& Magnadi, 2016; Pratama \& Magnadi, 2017; Norhermaya \& Soesanto, 2016; Hanafi, 2020). Semakin tinggi tingkat kepercayaan konsumen kepada penjual, maka semakin tinggi keinginan konsumen untuk membeli produk (Juliana, Noval, Hubner, \& Bernarto, 2020; Adiwijaya, Kaihatu, Nugroho, \& Kartika, 2017; Sensuse, Pratama, Satria, Noprissom, \& Ramadhan, 2017; Hadining, Haryanti, \& Munajat, 2020)

\section{H3 : Kepercayaan berpengaruh terhadap Minat Beli}

\subsubsection{Kualitas Antarmuka, Kepercayaan dan Minat Beli}

Konsumen akan melihat secara visual antarmuka (interface) yang memberikan infromasi detail mengenai produk yang ditawarkan oleh penjual pada aplikasi belanja online. Antarmuka yang interaktif, memberikan informasi yang jelas, tepat, dan lengkap akan menanamkan rasa percaya konsumen kepada penjual, bahwa penjual dapat diandalkan, jujur dan memiliki komitmen dalam memegang janji (Halim, 2019; Apriyana, Ariyanti, \& Sumrahadi, 2017). Rasa percaya konsumen bahwa produsen 
berperilaku saling menguntungkan dan tidak akan melakukan tindakan oportunis akan mendorong minat konsumen untuk melakukan pembelian secara online (Juliana, Noval, Hubner, \& Bernarto, 2020; Hadining, Haryanti, \& Munajat, 2020).

H4 : Kualitas antarmuka melalui kepercayaan berpengaruh terhadap Minat Beli

Tabel 1. Operasionalisasi Variabel

\begin{tabular}{lllc}
\hline \multicolumn{1}{c}{ Variabel/ Konsep } & \multicolumn{1}{c}{ Indikator } & Skala \\
\hline Kualitas antarmuka (Patel, & 1. & Informatif & $1-10$ \\
Das, Chatterjee, \& Shukla, & 2. & Desain layout & \\
2020) & 3. & Visual & $1-10$ \\
\hline Kepercayaan (Roy, Dewit, \& & 1. & Kemampuan/kehandalan (ability) & \\
Aubert, 2001) & 2. & Integritas (memegang janji) & \\
& 3. & Saling menguntungkan (benevolence) & \\
\hline Minat beli (Alwafi \& & 1. & Minat traksaksional & \\
Magnadi, 2016) & 2. & Minat referensial & \\
& 3. & Minat preferensial & \\
\hline
\end{tabular}

Sumber: Rangkuman teori, 2021

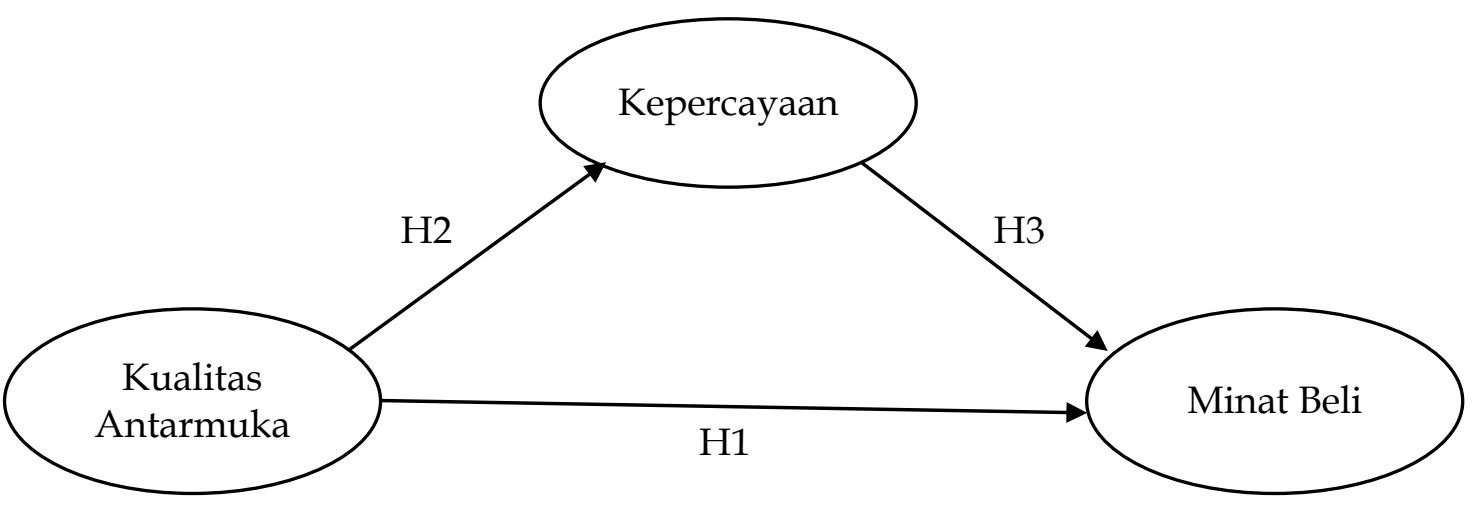

Gambar 1. Desain Penelitian

\subsection{Pengumpulan Data}

Penelitian ini dilakukan pada konsumen yang berbelanja online menggunakan aplikasi belanja Shopee.com. Populasi penelitian adalah seluruh konsumen yang menggunakan aplikadi Shopee.com. Pengambilan data penelitian ini menggunakan kuesioner yang disebarkan melalui googleform sehingga responden dapat langsung melakukan pengisian. Data penelitian dapat langsung ditarik dan diolah oleh peneliti. Pertanyaan dan pernyataan yang terdapat didalam kuisoner tersebut diukur menggunakan skala bipolar dari 1 - 10 dengan kriteria 1 sangat tidak setuju dan 10 sangat setuju (Mulyanto \& Wulandari, 2010).

\subsection{Metode Analisis}

Metode analisis dilakukan dengan pendekatan kuantitatif yang bertujuan menganalisis pengaruh kualitas antarmuka terhadap minat beli konsumen yang melakukan belanja 
online menggunakan aplikasi Shopee.com, dan dimediasi oleh kepercayaan konsumen kepada penjual. Analisa data penelitian menggunakan alat analisis dengan metode PLS (partial least square) dimana pengolahannya dilakukan dengan software Smart PLS 3.0. Langkah analisis meliputi pengujian outer dan inner model.

Pengujian outer menggunakan loading outer sebagai bentuk uji validitas dengan cut off $>0,7$ tetapi masih tetap dipertahankan jika nilai loadings outer tidak kurang dari 0,4. Cronbach's Alpha dengan cut off $>0,7$ dan nilai $\rho c$ (composite reliability) dengan cut off $>0,8$ digunakan untuk pengujian Reliabilitas. Pengujian inner model sebagai model structural menggunakan R2 dan Estimasi koefisien. Cut off untuk variabel laten endogenous R2 $>0,2$. Pengujian hubungan jalur dalam model structural menggunakan standar estimasi dengan cut off $\mathrm{p}$-value $<0,05$

\section{Hasil}

Dari kuisoner yang telah disebar didapatkan data penelitian sebanyak 152 responden yang merupakan konsumen aplikasi belanja online Shopee.com.

\subsection{Responden}

Data penelitian diperoleh dari 152 responden yang menjadi konsumen aplikasi belanja online Shopee.com dengan karakteristik yang dirangkum pada tabel 2.

Tabel 2. Data Responden

\begin{tabular}{ccc}
\hline \multicolumn{1}{c}{ Variabel } & Jumlah & Persen \\
\hline $\begin{array}{l}\text { Jenis Kelamin } \\
\text { - Perempuan }\end{array}$ & 97 & 63,8 \\
- Laki-laki & 55 & 36,2 \\
\hline Usia & & \\
- Dibawah 25 tahun & 63 & 41,4 \\
- Diatas 25 tahun & 89 & 58,6 \\
\hline Pendidikan Terakhir & & \\
- SLTA & 62 & 40,8 \\
- Diploma & 21 & 13,8 \\
- Sarjana & 57 & 37,5 \\
- Pascasarjana & 12 & 7,9 \\
\hline
\end{tabular}

Sumber: Data hasil kuesioner yang diolah, 2021

Tabel 2 menunjukkan data responden yaitu konsumen aplikasi belanja online Shopee.com yang menjadi sampel penelitian sebanyak 152 orang. Sebagian besar responden adalah perempuan, berusia diatas 25 tahun, dan berpendidikan terakhir SLTA.

\subsection{Analisis}

Pengujian instrumen pada tabel 3 menunjukkan seluruh indikator pada setiap variabel lebih besar dari 0,7 atau valid semuanya. Seluruh variabel juga telah reliabel karena telah memenuhi cut off yang digunakan dalam penelitian ini (cronbach alpha kualitas antarmuka 0,808; kepercayaan 0,812; dan minat beli 0,844 lebih besar dari 0,7 sedangkan 
composite reliability kualitas antarmuka 0,887; kepercayaan 0,888; dan minat beli 0,905 lebih besar daripada 0,8$)$.

Tabel 3. Uji Validitas dan Reliabilitas

\begin{tabular}{lcccc}
\hline \multicolumn{1}{c}{ Variabel/Indikator } & $\begin{array}{c}\text { Outer } \\
\text { Loading }\end{array}$ & $\begin{array}{c}\text { Crombah } \\
\text { Alpha }\end{array}$ & $\begin{array}{c}\text { Composite } \\
\text { Reliability }\end{array}$ & Kesimpulan \\
\hline Kualitas Antarmuka & & 0,808 & 0,887 & Reliabel \\
- Informatif & 0,849 & & & Valid \\
- Desain layout & 0,877 & & & Valid \\
- Daya tarik visual & 0,825 & & & Valid \\
\hline Kepercayaan & & 0,812 & 0,888 & Reliabel \\
- Kemampuan & 0,880 & & & Valid \\
- Integritas & 0,892 & & & Valid \\
- Saling menguntungkan & 0,781 & & & Valid \\
\hline Minat Beli & & 0,844 & 0,905 & Reliabel \\
- Minat traksaksional & 0,869 & & & Valid \\
- Minat referensial & 0,874 & & & Valid \\
- Minat preferensial & 0,874 & & & Valid \\
\hline
\end{tabular}

Sumber: Hasil Pengolahan, 2021

Model dapat diterima karena seluruh variabel endogen memiliki nilai $\mathrm{R}$ square lebih besar dari 0,2. Variabel endogen kepercayaan memiliki nilai $\mathrm{R}$ square 0,718 atau dalam kategori baik, dan variabel endogen minat beli dengan nilai $R$ square 0,693 dalam kategori baik.

Tabel 4. R Square

\begin{tabular}{lcc}
\hline \multicolumn{1}{r}{ Endogenous Variabel } & R Square & Kategori \\
\hline $\mathrm{R}^{2}$ & & \\
Kepercayaan & 0,718 & Baik \\
Minat Beli & 0,693 & Baik \\
\hline
\end{tabular}

Sumber: Data Primer yang diolah, 2021

Gambar 2 menunjukkan estimasi dari indikator ke variabel dan keterkaitan antar variabel. Seluruh indikator telah berkontribusi membentuk variabel masing-masing. Indikator desain layout merupakan indikator utama pembentuk kualitas antarmuka, integritas sebagai indikator utama kepercayaan, minat referensial dan minat preferensial sebagai indikator utama minat beli. 




Sumber: Data penelitian diolah, 2021

Gambar 2. Hasil Analisis

Tabel 5. Estimasi

\begin{tabular}{lcccl}
\hline \multicolumn{1}{c}{ Alur } & Jenis & Estimates & P-Value & Kesimpulan \\
\hline Kualitas Antarmuka $\rightarrow$ Minat Beli & Langsung & 0,156 & 0,103 & $\begin{array}{l}\text { Tidak } \\
\text { Signifikan }\end{array}$ \\
Kualitas Antarmuka $\rightarrow$ Kepercayaan Langsung & 0,848 & 0,000 & Signifikan \\
Kepercayaan $\rightarrow$ Minat Beli & Langsung & 0,698 & 0,000 & Signifikan \\
$\begin{array}{l}\text { Kualitas Antarmuka } \rightarrow \text { Kepercayaan } \\
->\text { Minat Beli }\end{array}$ & $\begin{array}{l}\text { Tidak } \\
\text { Langsung }\end{array}$ & 0,592 & 0,000 & Signifikan \\
\hline
\end{tabular}

Sumber: Data penelitian yang diolah, 2021

Hasil penelitian pada Tabel 5 menunjukkan kualitas antarmuka tidak berpengaruh terhadap minat beli, kualitas antarmuka berpengaruh terhadap kepercayaan, dan kepercayaan berpengaruh terhadap minat beli. Hal ini menunjukkan bahwa kepercayaan memediasi kualitas antarmuka terhadap minat beli konsumen pada aplikasi belanja online Shopee.com.

\section{Pembahasan}

\subsection{Pengaruh Kualitas Antarmuka Terhadap Minat Beli}

Kualitas antarmuka tidak berpengaruh terhadap minat beli konsumen pada aplikasi belanja online Shopee.com. Konsumen yang melihat antarmuka pada layar telepon pintarnya yang memiliki kombinasi gambar, warna dan kalimat yang menyatu menjadi sebuah tampilan visual yang terbukti tidak membangkitkan keinginan untuk membeli. Kualitas antarmuka tidak menciptakan daya pikat bagi konsumen untuk membeli 
barang dan jasa melalui aplikasi belanja online. Kualitas antarmuka, layout website, dan daya tarik visual yang terdapat pada aplikasi belanja online bukan penentu keinginan kosumen untuk membeli, akan tetapi terdapat faktor lain yang harus dipertimbangkan oleh konsumen ketika melakukan transasksi jarak jauh yang rentan dengan risiko penipuan dan manipulasi dalam informasi, gambar, dan visualisasi.

Temuan ini tidak mendukung penelitian sebelumnya (Wuryandari, Vincentiar, \& Permana, 2019; Joewono, Ramadoni, \& Yumte, 2019) yang menunjukkan bahwa kualitas antarmuka menentukan ada tidaknya minat konsumen untuk membeli. Akan tetapi, hasil penelitian menguatkan penelitian sebelumnya (Patel, Das, Chatterjee, \& Shukla, 2020) yang menunjukkan bahwa terdapat faktor lain yang mendorong minat konsumen membeli produk pada aplikasi belanja online. Tidak adanya pengaruh dimungkinkan karena adanya konten yang ditampilkan secara visual hanya menarik perhatian atau hal lainnya tidak sampai menjadikan minat.

\subsection{Pengaruh Kualitas Antarmuka Terhadap Kepercayaan}

Kualitas antarmuka berpengaruh terhadap kepercayaan konsumen pada aplikasi belanja online Shopee.com. Konsumen aplikasi belanja online Shopee.com membutuhkan adanya unsur kepercayaan yang dapat ditelusuri dari reputasi penjual dan testimoni konsumen sebelumnya. Jika penjual dapat dipercaya, maka penjual memiliki jumlah bintang lebih dari 4 bintang pada skala 1 sampai dengan 5 . Selain dari jumlah bintang, jumlah produk yang dibeli juga menunjukkan tingkat kepercayaan konsumen kepada penjual.

Temuan ini mendukung penelitian sebelumnya (Jin \& youngho Jin, 2006; Roy, Dewit, \& Aubert, 2001; Halim, 2019; Apriyana, Ariyanti, \& Sumrahadi, 2017) yang menyatakan bahwa kualitas antarmuka mempengaruhi kepercayaan konsumen. Baik buruknya tampilan, visual, dan ketajaman informasi berdampak pada ada tidaknya kepercayaan konsumen kepada penjual. Konten yang lebih informatif, desain yang artistik dan visualisasi yang mudah dimengerti konsumen hendaknya menjadi perhatian sejalan dengan aplikasinya.

\subsection{Pengaruh Kepercayaan Terhadap Minat Beli}

Kepercayaan mempengaruhi minat beli konsumen pada aplikasi belanja online Shopee.com. Berbelanja online tidak memungkinkan konsumen melakukan tatap muka, tetapi hanya dapat berkomunikasi interaktif melalui kolom tanya jawab, oleh karena itu konsumen memiliki persepsi bahwa penjual yang dapat dipercaya adalah penjual yang mampu memenuhi janji dan komitmennya kepada konsumen.

Temuan ini sesuai dengan beberapa penelitian terbaru sebelumnya (Hadining, Haryanti, \& Munajat, 2020; Hanafi, 2020; Juliana, Noval, Hubner, \& Bernarto, 2020) dimana kepercayaan berpengaruh terhadap minat beli. Saran dan opini dari konsumen sebelumnya yang dapat dilihat pada kolom testimoni dapat mendorong minat konsumen untuk membeli. Karena itu, perlu perhatian lebih dari pemilik aplikasi untuk memantau testimoni sebagai evaluasi kepercayaan konsumen.

\subsection{Pengaruh Kualitas Antarmuka Terhadap Minat Beli Melalui Kepercayaan}

Kepercayaan memediasi pengaruh kualitas antarmuka terhadap minat beli konsumen pada aplikasi belanja online Shopee.com. Demikian pentingnya unsur kepercayaan ini

\footnotetext{
“LPPM Universitas Pelita Bangsa" $\quad$ Page | 187
} 
sehingga minat transaksi online hanya akan terjadi apabila konsumen yakin bahwa penjual dapat dipercaya.

Temuan penelitian ini menjawab hasil penelitian sebelumnya (Patel, Das, Chatterjee, \& Shukla, 2020) dimana kualitas antarmuka yang dapat dilihat dalam bentuk visual pada telepon pintar tidak berpengaruh terhadap minat konsumen untuk membeli suatu produk secara online. Temuan ini juga membuktikan bahwa kepercayaan memegang peranan penting dalam menentukan sikap seseorang untuk bertindak melakukan transaksi online pada situas belanja online. Kualitas antarmuka dianggap penting oleh konsumen untuk mendapatkan kepercayaan sehingga konsumen tersebut terdorong untuk membeli dan melakukan transaksi online. Karena itu, tampilan aplikasi yang berkenaan dapat dipantaunya tingkat kepercayaan perlu ditonjolkan..

\section{Kesimpulan}

Kualitas antarmuka tidak berpengaruh terhadap minat beli, kualitas antarmuka berpengaruh terhsadap kepercayaan, dan kepercayaan berpengaruh terhadap minat beli. Hal ini menunjukkan bahwa kepercayaan memediasi pengaruh kualitas antarmuka terhadap minat beli konsumen pada aplikasi belanja online Shopee.com. Demikian pentingnya unsur kepercayaan ini sehingga transaksi online hanya akan terjadi apabila konsumen yakin bahwa penjual dapat dipercaya.

Penelitian lanjutan dapat mengungkap faktor selain kualitas antar muka terhadap minat pembelian online. Selain itu perlu juga ditelaah variabel lain yang berpotensi menjadi pemediasi.

\section{Daftar Pustaka}

Adiwijaya, M., Kaihatu, T., Nugroho, A., \& Kartika, E. W. (2017). The Issues of Risk, Trust, and Customer Intention: A Search for The Relationship. Risk governance $\mathcal{E}$ control: financial markets $\mathcal{E}$ institutions, 7(1), 82-90.

Aladwani, A. M., \& Palvia, P. C. (2002). Developing and validating an instrument for measuring user-perceived web quality. Information $\mathcal{E}$ Management, 39, 467-476.

Alwafi, F., \& Magnadi, R. H. (2016). Pengaruh Persepdi Keamanan, Kemudahan Bertransaksi, Kepercayaan Terhadap Toko dan Pengalaman Berbelanja Terhadap Minat Beli secara Online pada Situs Jual Beli Tokopedia.com. Diponegoro Journal of Management, 5(2), 1-15.

Apriyana, A. H., Ariyanti, M., \& Sumrahadi. (2017). Pengaruh Usability Interface Terhadap Kepercayaan Konsumen pada Website E-commerce B2C. e-Proceeding of Management, 4(3), pp. 2221-2228.

databoks. (2021, Juli 22). Retrieved from https://databoks.katadata.co.id/tags/ecommerce

databoks. (2021, Juli 22). Retrieved from https://databoks.katadata.co.id/tags/ecommerce

Hadining, A. F., Haryanti, S. A., \& Munajat, T. R. (2020). Determined Consumers Online Purchase Intention Factors by Considering Risk and E-trust. Jurnal Muara Ilmu Ekonomi dan Bisnis, 4(2), 293-300. 
Halim, H. (2019). Pengaruh User Interface Quality, Information Quality, Perceived Security, Perceived Privacy, Belief, dan Knowledge Yerhadap Niat Beli Barang di WEbsite E-commerce di Indonesia. Jurnal Manajemen Bisnis dan Kewirausahaan, $3(2), 63-69$.

Hanafi, M. I. (2020). Pengaruh Kepercayaan, Keamanan, Kemudahan dan Risiko Terhadap Minat Beli Via Media Online Butuhbaju.com. PERFORMA: Jurnal Manajemen dan Start-Up Bisnis, 4(6), 921-932.

Jin, B., \& youngho Jin, O. S. (2006). The Moderating Effect of Online Purchase Experience on the Evaluation of Online Store Attributes and the Subsequent Impact on Market Response Outcomes. Advances in Consumer Research, 33, 203-211.

Joewono, S., Ramadoni, W., \& Yumte, A. (2019). Pengaruh Tampilan Antar Muka dan Kualitas Layanan Terhadap Minat Beli (Studi Kasus pada Go-Food di Kota Malang dan Surabaya). Jurnal EKSEKUTIF, 16, 70-86.

Juliana, Noval, T., Hubner, I. B., \& Bernarto, I. (2020). Ease Of Use Dan Trust Terhadap Purchase Intention Melalui Customer Satisfaction Pada Situs Web Tokopedia. Jurnal Ecodemica, 4(2), 217-229.

Kinasih, B. S., \& Albari. (2012). Pengaruh Persepsi Keamanan dan Privasi Terhadap Kepuasan dan Kepercayaan Konsumen Online. Jurnal Siasat Bisnis, 16(1), 25-38.

Lin, C.-Y., Yeh, J.-Y., \& Yu, Y.-T. (2016). The Influence of Privacy Calculus, User Interface Quality and Perceived Value on Mobile Shopping. Journal of Economics, Business and Management, 4(10), 567-572.

Mulyanto, H., \& Wulandari, A. (2010). Penelitian: Metode dan Analisis. Semarang: CV. Agung.

Norhermaya, Y. A., \& Soesanto, H. (2016). Analisis Pengaruh Kepuasan Pelanggan Terhadap Kepercayaan dan Loyalitas Pelanggan untuk Meningkatkan Minat Beli Ulang (Studi pada Online Store Lazada.co.id). Diponegoro Journal of Management, $5(3), 1-13$.

Nurdian, G. (2021, Februari 13). Retrieved from https://grahanurdian.com/ecommerce-indonesia-2021/

Patel, V., Das, K., Chatterjee, R., \& Shukla, Y. (2020). Does the interface quality of mobile shopping apps affect purchase intention? An empirical study. Australasian Marketing Journal(28), 300-309.

Pratama, R. B., \& Magnadi, R. H. (2017). Analisis Pengaruh Promosi dan Persepsi Keamanan Terhadap Kepercayaan Serta Omplikasinya Terhadap Minat Beli di E-Commerce (Studi Pada Pengguna Blibli,com). Diponegoro Journal of Management, 6(3), 1-11.

Roy, M. C., Dewit, O., \& Aubert, B. A. (2001). The Impact of Interface Usability on Trust in Web Retailers. INternet Research: Electronic Networking Applications and Policy, 11(5), 388-398.

Sensuse, D. I., Pratama, A. A., Satria, D., Noprissom, H., \& Ramadhan, A. (2017). Investigating Factors of Purchase Intention Based on Social Commerce, Trust and Follower in Social Media. International Conference on Information Technology Systems and Innovation (ICITSI), (pp. 315-319). Bandung.

Vu, T. A., Thang, D. M., \& Mai, D. T. (2020). Customer's Behavior on Intention to Purchase on Online Shopping in Vietnam. Journal of Business and Management Sciences, 8(3), 85-88. 
Watulingas, E. B., \& Permana, D. (2020). The Influence of User Interface, User Experience and Digital Marketing toward Purchase Intention. International Humanities and Applied Science Journal, 3(2), 35-39.

Wuryandari, N. E., Vincentiar, P., \& Permana, D. (2019). Buying Intention through User Interface Design. European Research Studies Journal, 22(3), 470-479. 